\title{
KEBIJAKAN PENINGKATAN PEMUNGUTAN IJIN MENDIRIKAN BANGUNAN (IMB) SEBAGAI UPAYA PENINGKATAN PENDAPATAN ASLI DAERAH (PAD) DI KABUPATEN KUDUS
}

\author{
Refandy, Subarkah dan Suparnyo \\ Email : refandyrezapratama939@gmail.com,subarkah_sh@yahoo.com, \\ suparnyo@umk.ac.id \\ Fakultas Hukum Universitas Muria Kudus
}

\begin{abstract}
ABSTRAK
Retribusi Izin Mendirikan Bangunan (IMB) merupakan bagian dari Pendapatan Asli Daerah (PAD). Dalam meningkatkan PAD melalui IMB, Pemerintah Daerah Kabuparten Kudus mengeluarkan Peraturan Daerah Nomor 15 Tahun 2015 tentang Retribusi Izin Mendirikan Bangunan. Retribusi sebagai penyumbang Pendapatan Asli Daerah Kabupaten Kudus, harus berjalan dengan maksimal, hal ini dikarenakan dari PAD digunakann kembali untuk mensejahterakan masyarakat. Hasil dari Retribusi IMB selain untuk membiayaai pembangunan di Kabupaten Kudus, pemberian IMB juga untuk mengatur/mengendalikan dan menata bangunan masyarakat supaya tertib dan rapi sesuai dengan standar bangunan yang layak huni dan aman bagi penghuninya. Metode pendekatan dalam penelitian ini yaitu yuridis empiris, spesifikasi dalam penelitian ini yaitu deskriptif analitis. Dalam penelitian ini menggunakan purposive sampling. Pengumpulan data dalam penelitian ini yaitu dengan wawancara dan studi kepustakaan dan analisis data yang digunakan yaitu analisis kualitatif. Hasil penelitian ini dapat diketahui bahwa dalam upaya meningkatkan pendapatan asli daerah (PAD) khususnya di bidang Retribusi Ijin Mendirikan Bangunan (IMB) dengan menerbitkan Peraturan Daerah Nomor 4 Tahun 2014 tentang Bangunan Gedung. Namun dalam Perda Kabupaten Kudus Nomor 4 Tahun 2014 tidak mengatur "Pemutihan" IMB. Dengan mengatur "Pemutihan" bagi bangunan yang belum memiliki IMB diharapkan dapat meningkatkan retribusi IMB. Kendala Kantor Pelayanan Perizinan Terpadu Satu Pintu Kabupaten Kudus (KP2TSP) dalam mengimplementasikan Peraturan Daerah Nomor 15 Tahun 2011 Tentang Retribusi Ijin Mendirikan Bangunan. Kendala-kendala yang muncul yaitu sebagai berikut, dari sisi aturan Perda Nomor 4 Tahun 2014 tentang Bangunan Gedung Dalam Perda bangunan gedung tidak mengatur "Pemutihan" terhadap bangunan-bangunan yang belum mempunyai IMB. Dengan pemutihan dapat meningkatkan Retribusi IMB Keterbatasan Sumber Daya Manusia, Bangunan tidak sesuai dengan gambar yang ada dalam IMB, Rendahnya kesadsaran masyarakat terhadap Izin Mendirikan Bangunan, Kurangnya pengetahuan masyarakat, Waktu dan biaya, Kurangnya pengawasan.Peran masyarakat dalam Izin mendirikan Bangunan sangat dibutuhkan, karena Izin Mendirikan Bangunan berhubungan langsung dengan Rencana Tata Ruang Wilayah dan sekaligus dapat meningkatkan Pendapatan Asli Daerah dari sektor Retribusi IMB.
\end{abstract}

Kata Kunci : Kebijakan Pemungutan IMB, Pendapatan Asli Daerah (PAD) 


\section{PENDAHULUAN}

Perubahan Undang-Undang Dasar Negara Republik Indonesia Tahun 1945, berdampak pada kebijakan tentang Pemerintahan Daerah. Dampak yang paling terasa adalah pelaksanaan otonomi Daerah, alasan dari perubahan tersebut adalah untuk menampung semangat otonomi Daerah dalam memperjuangkan kesejahteraan masyarakat di daerah. Otonomi Daerah memberi keleluasaan kepada daerah untuk mengurus urusan rumah tangganya sendiri secara demokratis dan bertanggungjawab dalam kerangka Negara Kesatuan Republik Indonesia.

Pasal 1 angka 6 Undang Undang Nomor 23 Tahun 2014 tentang Pemerintahan Daerah (selanjutnya disebut UUPD) adalah hak, wewenang, dan kewajiban daerah otonom untuk mengatur dan mengurus sendiri Urusan Pemerintahan dan kepentingan masyarakat setempat dalam sistem Negara Kesatuan Republik Indonesia.

Tujuan utama dari pelaksanaan Otonomi Daerah adalah untuk mendekatkan pemerintah dengan masyarakat melalui pelayanan, dengan harapan pelayanan dari pemerintah kepada masyarakat dapat lebih terkontrol dan pengawasan masyarakat kepada Pemerintah menjadi lebih kuat dan nyata.

\section{Berlakunya Undang-undang} Pemerintahan Daerah, maka sentralisme kekuasaan yang dulu terpusat pada Pemerintahan Pusat sekarang sudah tidak lagi. Otonomi Daerah adalah hak, wewenang, dan kewajiban Daerah Otonom untuk mengatur dan mengurus sendiri urusan Pemerintahan dan kepentingan masyarakat setempat sesuai dengan Peraturan Perundang-undangan. Adanya Otonomi Daerah, Pemerintah
Daerah diberi wewenang untuk mengurus rumah tangganya sendiri termasuk mengelola keuangan dan diberi wewenang untuk mengelola potensi daerah yang dapat meningkatkan Pendapatan Asli Daerah (PAD). Salah satu sumber Pendapatan Asli Daerah Kabupaten Kudus yaitu dari sektor pemungutan retribusi Izin Mendirikan Bangunan yang diatur dalam Peraturan Daerah Nomor 15 Tahun 2011 tentang Retribusi Izin Mendirikan Bangunan (IMB).

Retribusi Izin Mendirikan Bangunan merupakan salah satu sumber Pendapatan Asli Daerah Kabupaten Kudus yang dikelola oleh Kantor Pelayanan Perizinan Terpadu Satu Pintu (KP2TSP)

Kabupaten Kudus. Kabupaten Kudus merupakakan Kabupaten terkecil yang ada di Provinsi Jawa Tengah, dengan pendapatan yang cukup besar, Kabupaten Kudus terkenal dengan Industri Rokoknya. Untuk menjaga agar Kabupaten Kudus tetap menjadi kota yang bersih dan kota yang tertata dengan rapi, maka Pemerintah Kabupaten Kudus menertibkan setiap bangunan, dengan tujuan untuk menertibkan bangunan dan sekaligus menambah Pendapatan Asli Daerah dari sector retribusi Izin Mendirikan Bangunan.

Retribusi sebagai penyumbang Pendapatan Asli Daerah Kabupaten Kudus, harus berjalan dengan maksimal, hal ini dikarenakan dari PAD digunakann kembali untuk mensejahterakan masyarakat. Permasalahan yang terjadi di lapangan adalah apakah bangunan masyarakat Kudus sudah memiliki Ijin Mendirikan Bangunan (IMB) atau belum. Hasil dari Retribusi IMB selain untuk membiayaai pembangunan di Kabupaten Kudus, 
pemberian IMB juga untuk mengatur/mengendalikan dan menata bangunan masyarakat supaya tertib dan rapi sesuai dengan standar bangunan yang layak huni dan aman bagi penghuninya. Oleh sebab itu dalam mengajukan IMB harus disertakan gambar bangunan ke Kantor Pelayanan Perizinan Terpadu Satu Pintu (KP2TSP), tujuannya adalah untuk dipelajari oleh petugas.

Permasalahan sebagaimana tersebut di atas, apabila bisa ditangani dengan baik akan menambah Pendapatan Asli Daerah Kabupaten Kudus. Oleh sebab itu perlu bantuan semua pihak, baik aparat Pemerintah Kabupaten Kudus dan Masyarakat harus saling mendukung dalam hal pengurusan dokumen Izin Mendirikan Bangunan.

Berdasarkan latar belakang sebagaimana diuraikan di atas, maka permasalahan yang akan diteliti yaitu sebagai berikut:

1) Bagaimana kebijakan Pemerintah Kabupaten Kudus dalam upaya meningkatkan Pendapatan Asli Daerah (PAD) khususnya di bidang Retribusi Ijin Mendirikan Bangunan (IMB) ?

2) Apa yang menjadi kendala Kantor Pelayanan Perizinan Terpadu Satu Pintu Kabupaten Kudus (KP2TSP) dalam mengimplementasikan Peraturan Daerah Nomor 15 Tahun 2011 tentang Retribusi Ijin Mendirikan Bangunan?

3) Bagaimana peran masyarakat dalam mendukung kebijakan peningkatan penerimaan retribusi IMB ?

\section{METODE PENELITIAN}

Penelitian ini menggunakan metode pendekatan yuridis empiris.
Menurut Dyah Ochtorina Susanti dan A'an Efendi, yuridis empiris artinya penelitian hukum sosiologis/empiris meliputi penelitian terhadap identifikasi hukum (hukum tidak tertulis) dan penelitian terhadap efektifitas hukum. ${ }^{107}$ Selain menjelaskan legalitas aturanaturan asas hukum dan aspek-aspek hukum tentang Kebijakan Peningkatan Pendapatan Asli Daerah dari sektor IMB juga untuk mengetahui implementasi Peraturan Daerah Kabupaten Kudus Nomor 15 Tahun 2011 tentang Retribusi Izin Mendirikan Bangunan.

Spesifikasi dalam penelitian ini yaitu deskriptif analitis dengan penentuan sampel yang digunakan adalah purposive sampling. Data yang digunakan dalam penelitian ini adalah data primer sebagai data utama dan data sekunder sebagai data pendukung. Data primer diperoleh melalui wawancara, sedangkan data sekunder diperoleh dengan melakukan studi kepustakaan.

\section{HASIL PENELITIAN DAN PEMBAHASAN}

\section{Kebijakan \\ Pemerintah \\ Kabupaten Kudus Dalam Upaya Meningkatkan Pendapatan Asli Daerah (PAD) Khususnya di Bidang Retribusi Ijin Mendirikan Bangunan (IMB)}

Verguning atau izin didefinisikan sebagai suatu perbuatan administrasi negara yang memperkenankan perbuatan yang secara umum tidak dilarang dalam peraturan perundangundangan asalkan dilakukan sesuai dengan syarat-syarat tertentu yang

\footnotetext{
${ }^{107}$ Dyah Ochtorina Susanti dan A'an Efendi, Penelitian Hukum (Legal Research) ,Sinar Grafika, Jakarta, 2014, hlm. 18.
} 
ditentukan dalam peraturan hukum yang berlaku. ${ }^{108}$ Menurut Ridwan H.R. izin adalah perbuatan hukum administrasi negara bersegi satu yang mengaplikasikan peraturan dalam hal konkreto berdasarkan persyaratan dan prosedur sebagaimana ditetapkan oleh ketentuan peraturan perundangundangan. $^{109}$

Tujuan dari IMB adalah untuk melegalkan bangunan sesuai dengan tata ruang yang telah ditentyukan oleh Pemerintah, selain itu dengan adanya IMB dapat meningkatkan Pendapatan Asli Daerah (selanjutnya disebut PAD). Retribusi PAD yang masuk ke kas Pemerintah Daerah dapat menambah pendapatan daerah. Pemerintah Daerah dalam membiayai penyelenggaraan pemerintahan, Pemerintah Daerah akan menggali dan mencari potensi daerah dengan tujuan untuk meningkatkan Pendapatan Asli Daerah (PAD).

Dalam menunjang untuk meningkatkan Pendapatan Asli Daerah (PAD) dibidang perizinan khususnya Izin Mendirikan Bangunan (IMB), Pemerintah Kabupaten Kudus menerbitkan Peraturan Daerah Nomor 15 Tahun 2011 tentang Retribusi Izin Mendirikan Bangunan (selanjutnya disebut Perda Retribusi IMB). Pasal 1 ayat (8) Perda Retribusi IMB Kabupaten Kudus menjelaskan, bahwa "Izin Mendirikan Bangunan yang selanjutnya disingkat IMB adalah Izin yang dikeluarkan oleh Bupati dengan memberikan hak kepada pemiliknya untuk mendirikan bangunan sesuai ketentuan peraturan perundang-

${ }^{108}$ SF Marbun dan Mahfud MD, Pokok-pokok Hukum Administrasi Negara, Liberty, Yogyakarta, 2006 hlm 95

109 Ridwan HR, Hukum Administrasi Negara, UII Press, Cetakan Kedua, Yogyakarta, 2003, hlm. 152 undangan yang berlaku". Retribusi Izin Mendirikan Bangunan menurut Pasal 1 ayat (9) Perda Retribusi IMB adalah pembayaran atas pemberian Izin Mendirikan Bangunan kepada orang pribadi atau badan di lokasi tertentu.

Secara keseluruhan Pendapatan Asli Kabupaten Kudus pada tahun 2015 yaitu Rp 255, 270, 000, 000,- (dua ratus lima puluh lima milyar dua ratus tujuh puluh juta rupiah), pada akhir tahun 2015 dapat terealisasi melebihi target. Pada tahun 2016 Pemerintah Daerah Kabupaten Kudus mentargetkan PAD sebesar Rp 287.096.753.000,- (dua ratus delapan puluh tujuh milyar Sembilan puluh enam juta tujuh ratus lima puluh tiga ribu rupiah). Kepala DPPKD Kabupaten Kudus Eko Jumartono mengatakan, pada bahwa tahun 2016 PAD Kabupaten Kudus sesuai dengan target sebagaimana tersebut di atas. PAD Kabupaten Kudus tersebut di atas diperoleh dari empat sektor penerimaan, yaitu dari pajak daerah, retribusi daerah, pengelolaan kekayaan daerah dan lainlain PAD yang sah. ${ }^{110}$

Dari sektor retribusi Izin Mendirikan Bangunan mendapatkan pemasukan sebesar Rp 3. 733. 314. 500,- (tiga milyar tujuh ratus tiga puluh tiga juta tiga ratus empat belas ribu lima ratus rupiah).

Biaya Retribusi Izin Mendirikan Bangunan di Kabupaten Kudus sebagaimana diatur Pasal 8 Perda IMB, yaitu sebagai berikut :

(1) Struktur dan besarnya tarif berdasarkan luas tempat usaha dan tarif gangguan

\footnotetext{
${ }^{110}$ Eko Jumartono, wawancara pribadi, Kepala Dinas Pengelolaan Pendapatan Kekayaan Daerah (DPPKD) Kabupaten Kudus, tanggal 8 Agustus 2017.
} 
usaha/kegiatan

yang

dimohonkan izin.

(2) Struktur dan besarnya tarif retribusi ditetapkan berdasarkan rumus sebagai berikut :

Retribusi Izin Gangguan = Luas Tempat Usaha X Tarif Gangguan

(3) Penghitungan tarif Retribusi Izin Gangguan didasarkan pada hasil perkalian luas tempat usaha dengan tarif gangguan.

(4) Tarif gangguan sebagaimana dimaksud pada ayat (3)didasarkan pada tingkat gangguan besar, gangguan sedang, dan gangguan kecil.

(5) Tarif Gangguan sebagaimana tercantum dalam Lampiran yang merupakan bagian tidak terpisahkan dari Peraturan Daerah ini.

\section{Kendala-Kendala yang Dihadapi} Kantor Pelayanan Perizinan Terpadu Satu Pintu Kabupaten Kudus (KP2TSP) dalam Mengimplementasikan Retribusi Ijin Mendirikan Bangunan

Kendala-kendala dalam meberikan IMB di Kabupaten Kudus menurut Fellaini yaitu sebagai berikut : ${ }^{11}$

1. Dari sisi aturan Perda Nomor 4 Tahun 2014 tentang Bangunan Gedung

Dalam Perda bangunan gedung tidak mengatur "Pemutihan" terhadap bangunan-bangunan yang belum mempunyai IMB.

111 Fellaini, wawancara pribadi, Staf Kantor Dinas Badan Penanaman Modal dan Pelayanan Perizinan Terpadu Kabupaten Kudus, tanggal 3 Maret 2017
Dengan pemutihan dapat meningkatkan Retribusi IMB.

2. Keterbatasan Sumber Daya Manusia

Idealnya PTSP memiliki staf teknis, seperti ahli dalam penilaian AMDAL, Kesehatan, Sipil dan Transportasi, umumnya staf tersebut berada di bawah Dinas atau Instansi asalnya bukan di PTSP. Namun yang terjadi saat ini tenaga ahli sebagaimana tersebut berada di PTSP bukan di Dinas asalnya.

3. Bangunan tidak sesuai dengan gambar yang ada dalam IMB

Pada umumnya sebelum mengajukan permohonan IMB, pemohon sudah memulai pembangunan terlebih dahulu, artinya bangunan dalam proses pengerjaan, IMB baru diurus. Perubahan bangunan juga tidak dilaporkan ke Kantor Perizinan, hal ini jelas sangat merugikan Pemerintah Daerah Kabupaten Kudus, karena mengurangi pemasukan pendapatan daerah.

4. Rendahnya kesadsaran masyarakat terhadap Izin Mendirikan Bangunan

Rendahnya kesadaran masyarakat untuk mengurus Izin Mendirikan Bangunan (IMB) diakibatkan karena kurangnya sosialisasi yang dilakukan instansi terkait terhadap masyarakat, dampaknya masyarakat dibayang-bayangi dengan biaya perizinan yang sangat tinggi. Pentingnya IMB dimiliki masyarakat, tidak hanya sebagai pelengkap legalitas bangunan yang dimiliki. Tapi, pengurusan IMB itu sangat 
berpengaruh pada peningkatan Pendapatan Asli Daerah (PAD).

5. Kurangnya pengetahuan masyarakat

Dalam hal ini berlaku bagi masyarakat yang melakukan renovasi rumah. Masyaraakat pada umumnya yang sedang merenovasi rumah tidak mengajukan permohonan IMB terlebih dahulu, tetapi membongkar bangunan terlebih dahulu dan baru mengururs IMB apabila ada petugas yang mendatangai lokasi bangunan, barulah pemilik bangunan mengajukan IMB. Sesuai aturan yang berlaku, maka pemilik bangunan mengajukan izin terlabih dahulu, setelah izin keluar baru melakukan pembongkaran bangunan yang akan direnovasi, sebagaimana diatur Pasal 1 angka 1 Perauran Menteri Pekerjaan Umum dan Perumahan Rakyat Nomor 5/PRT/ M/2016 tentang Izin Mendirikan Bangunan Gedung.

6. Waktu dan biaya

Jadwal penyampaian instruksi dari Pemerintah Kabupaten kepada kecamatan, kelurahan sering terlambat dari waktu yang ditentukan. Kurang tepatnya penilaian tentang tafsiran biaya bangunan karena kesulitan yang ditemui petugas Dinas Pekerjaan Umum di lapangan, sebab petugas belum banyak pengalaman dan masyarakat kurang cepat memberikan informasi tentang bangunan, sehingga tafsiran biaya untuk bengunan hanya berdasarkan pikiran yang menyebabkan

retribusi kurang cocok dengan kondisi bangunan.

7. Kurangnya pengawasan Masih kurangnya pengawas di lapangan berpengaruh terhadap proses pekerjaan mendirikan bangunan memakan waktu yang lama. Tentunya hal ini juga berpengaruh terhadap peningkatan retribusi Izin Mendirikan Bangunan.

\section{Peran Masyarakat Dalam}

Mendukung

Peningkatan

\section{Retribusi IMB}

Peran masyarakat dalam Izin mendirikan Bangunan sangat dibutuhkan, karena Izin Mendirikan Bangunan berhubungan langsung dengan Rencana Tata Ruang Wilayah. Pengertian ruang menurut Pasal 1 angka 6 Perda Nomor 16 Tahun 2012 tentang Rencana Tata Ruang Wilayah Kabupaten Kudus Tahun 2012-2032, adalah wadah yang meliputi ruang darat, ruang laut dan ruang udara, termasuk ruang di dalam bumi sebagai satu kesatuan wilayah, tempat manusia dan makhluk lain hidup, melakukan kegiatan dan memelihara kelangsungan hidupnya. Tata ruang menurut Pasal 1 angka 7 adalah wujud struktur ruang dan pola ruang. Berdasarkan Pasal 1 angka 7 sebagaimana tersebut di atas, maka tata ruang hubungannya sangat erat dengan kondisi fisik geografis suatu wilayah.

Berdasarkan hasil penelitian dan pembahasan, retribusi IMB Kabupaten Kudus sebagai salah satu Pendapatan Asli Daerah masih dapat ditingkatkan, meskipun ada hambatan sebagaimana tersebut di atas. Namun bukan tidak mungkin Pendapatan Asli Daerah Kabupaten Kudus dari sktor retribusi 
IMB dapat ditingkatkan, dengan terbitnya Peraturan Daerah Nomor 4 Tahun 2014 tentang Bangunan Gedung dapat menjadi pedoman dalam menerbitkan IMB. Namun, dalam Perda Nomor 4 Tahun 2014 tidak mencantumkan adanya "Pemutihan", artinya memberikan kemudahan bagi masyarakat yang belum mempunyai IMB dengan cara mengurangi biaya retribusi berdasarkan tahun bangunan tersebut dibangun. Cara ini menurut penulis sangat efektif untuk meningkatkan Pendapatan Asli Daerah dari sektor Retribusi IMB. Cara "Pemutihan" sudah sering dilakukan pada sektor Pajak kendaraan Bermotor, yang tujuannya tidak lain adalah untuk meningkatkan pendapatan dari sektor Pajak Kendaraan bermotor, tidak ada salahnya cara seperti tersebut di atas diterapkan untuk meningkatkan Retribusi IMB.

Payung hukum program pemutihan IMB dapat dituangkan dalam Peraturan Bupati Kudus, sebagai dasar pertimbangan pemutihan IMB, yaitu sebagai berikut :

1. Alasan Pemutihan

a. Masih banyak bangunan yang didirikan belum memiliki IMB;

b. Menciptakan tertib administrasi bangunan;

c. Pengendalian pemanfaatan tata ruang;

d. Meningkatkan kesadaran masyarakat akan pentingnya IMB.

2. Tujuan Pemutihan

a. Memberikan aspek legal bangunan di Kabupaten Kudus;

b. Penataan dan penertiban pemanfatan ruang sesuai dengan rencana tata ruang Kabupaten Kudus; c. Mendorong peningkatan kesadaran masyarakat;

d. Mendorong peningkatan Pendapatan Asli Daerah (PAD).

3. Ruang lingkup peruntukan Pemutihan IMB

3.1. Pemutihan imb tidak diberikan kepada :

a. Bangunan yang tidak sesuai dengan peruntukan lahan dalam Tata Ruang Kabupaten;

b. Bangunan yang berada diatas garis sempadan bangunan, garis sempadan sungai, garis sempadan pantai, kawasan resapan air dan kawasan rawan bencana;

c. Bangunan yang berdiri diatas tanah/lahan sedang dalam sengketa

d. Bangunan perumahan yang dilaksanakan oleh pengembang perumahan, kecuali bangunan yang sudah dimiliki perorangan dan telah di renovasi;

e. Bangunan yang tidak layak fungsi dan membahayakan.

3.2. Objek, Subjek dan Jangka Waktu Pelaksanaan :

a. Objek Bangunan pada tahun 2016 dan tahun sebelumnya yang belum mempunyai IMB dan yang sudah mempunyai IMB tetapi telah dilakukan penambahan luas bangunan;

b. Subjek pemutihan IMB adalah orang pribadi dan badan usaha;

c. Jangka waktu pelaksanaan pemutihan IMB selama 3 (tiga) tahun, terhitung mulai tanggal pengundangan peraturan bupati, termasuk 
tahapan

sosialisasi, pelaksanaan dan evaluasi.

4. Mekanisme Pemutihan IMB

a. Berkas permohonan disampaikan ke DPMKUKMPTSP, lewat petugas Front Office

b. Pemeriksaan/verifikasi berkas, oleh verifikator pada DPMKUKMPTSP

c. Pemeriksaan/peninjauan lapangan lokasi bangunan, dilakukan bersama-sama SKPD teknis, di dampingi oleh DPMKUKMPTSP

d. Rekomendasi SKPD teknis, untuk mengetahui boleh atau tidaknya IMB untuk diterbitkan. Jika diperbolehkan penerbitan IMB nya, kemudian membuat perhitungan besaran retribusi IMB yang harus disetor oleh pemohon.

e. Pembayaran retribusi IMB ke Rekening Kas Daerah

f. Penerbitan IMB yang ditanda tangani kepala DPMKUKMPTSP.

\section{Masa Waktu Penerbitan IMB}

Masa waktu penerbitan IMB pemutihan paling lama 5 (lima) hari setelah peninjauan lapangan dan persyaratan yang dinyatakan lengkap dan benar, artinya tim teknis diberi kesempatan hanya 5 hari untuk membuat kebijakan teknis dan perhitungan biaya.

\section{Kesimpulan}

Berdasarkan hasil penelitian dan pembahasan sebagaimana pada bab sebelumnya, maka dapat ditarik kesimpulan bahwa :
1. Kebijakan Pemerintah Kabupaten Kudus dalam upaya meningkatkan pendapatan asli daerah (PAD) khususnya di bidang Retribusi Ijin Mendirikan Bangunan (IMB) dengan menerbitkan Peraturan Daerah Nomor 4 Tahun 2014 tentang Bangunan Gedung. Namun dalam Perda Kabupaten Kudus Nomor 4 Tahun 2014 tidak mengatur "Pemutihan" IMB. Dengan mengatur "Pemutihan" bagi bangunan yang belum memiliki IMB diharapkan dapat meningkatkan retribusi IMB .

2. Kendala Kantor Pelayanan Perizinan Terpadu Satu Pintu Kabupaten Kudus (KP2TSP) dalam mengimplementasikan Peraturan Daerah Nomor 15 Tahun 2011 Tentang Retribusi Ijin Mendirikan Bangunan. Kendala-kendala yang muncul yaitu sebagai berikut :

a. Dari sisi aturan Perda Nomor 4 Tahun 2014 tentang Bangunan Gedung Dalam Perda bangunan gedung tidak mengatur "Pemutihan" terhadap bangunanbangunan yang belum mempunyai IMB. Dengan pemutihan dapat meningkatkan Retribusi IMB

b. Keterbatasan Sumber Daya Manusia

c. Bangunan tidak sesuai dengan gambar yang ada dalam IMB

d. Rendahnya kesadsaran masyarakat terhadap Izin Mendirikan Bangunan

e. Kurangnya pengetahuan masyarakat

f. Waktu dan biaya

g. Kurangnya pengawasan

3. Peran Masyarakat Dalam Mendukung Kebijakan Peningkatan Penerimaan Retribusi IMB. Secara umum kesadaran masyarakat masih 
kurang terhadap IMB, hal ini karena masyarakat dibayang-bayangi dengan biaya yang mahal dalam mengurus IMB. Peran masyarakat dalam Izin mendirikan Bangunan sangat dibutuhkan, karena Izin Mendirikan Bangunan berhubungan langsung dengan Rencana Tata Ruang Wilayah dan sekaligus dapat meningkatkan Pendapatan Asli Daerah dari sektor Retribusi IMB.

\section{Saran}

Berdasarkan pembahasan dan kesimpulan sebagaimana tersebut di atas, maka penulis memberikan saran sebagai berikut:

1. Kepada Pemerintah Daerah Kabupaten Kudus, membuat Peraturan Bupati tentang "Pemutihan" Izin Mendirikan Bangunan, dengan harapan dapat meningkatkan Pendapatan Asli Daerah, dapat menata kembali Rencana Tata Ruang Wilayah Kabupaten sekaligus memberikan kepastian hukum terhadap bangunan masyarakat.

2. Pemerintah Daerah untuk selalu mensosialisasikan tentang pentingnya memiliki IMB pada masyarakat.

3. Kepada Masyarakat, supaya segera mengurus proses permohonan IMB, secara tidak langsung masyarakat sudah ikut berperan dalam meningkatkan Pendapatan Asli Daerah sekaligus membantu pemerintah dalam menata Rencana Tata Ruang Wilayah Kabupaten.

\section{DAFTAR PUSTAKA}

Adrian Sutedi, 2008, Hukum Pajak Dan Retribusi Daerah, Ghalia Indonesia,Jakarta
Riant Nugroho, 2009, Public Policy, Elex Media Komputindo, Jakarta

Ridwan H.R, 2003, Hukum Administrasi Negara, UII Press, Cetakan Kedua, Yogyakarta

AW. Widjaja, 2005, Penyelenggaraan Otonomi di Indonesia, Raja Grafindo Persada, Jakarta

Bagir Manan, 2001, Menyongsong Fajar Otonomi Daerah, Pusat Studi Hukum FH UII, Yogyakarta

Bambang Sunggono, 2013, Metodologi Penelitian Hukum Cetakan ke-14, Rajawali Pers, Jakarta

Djoko Muljono, 2010, Hukum PajakKonsep, Aplikasi Dan Penuntun Praktis, Andi Offset, Yogyakarta

Dyah Ochtorina Susanti dan A'an Efendi, 2014, Penelitian Hukum (Legal Research),Sinar Grafika, Jakarta

H. M. Busrizalti, 2013, Hukum Pemda Otonomi Daerah dan Implikasinya, Total Media, Yogyakarta

H. Zainuddin Ali, 2010, Metode Penelitian hukum, Sinar Grafika, Jakarta

Khoirul Muluk, 2006, Desentralisasi dan Pemerintahan Daerah, Bayumedia Publishing, Malang

Panca Kurniwan dan Agus Purwanto, 2006, Pajak Daerah \& Retribusi Daerah di Indonesia., Bayumedia, Malang

Philipus M. Hadjon, 1993, Pengantar Hukum Perizinan, Yuridika, Surabaya

Ronni Hanitjo Soemitro, 1982, Metodologi Penelitian Hukum dan 
Jurimetri, Ghalia Indonesia, Jakarta

Sunarto, 2005, Pajak dan Retribusi Daerah, Amus dan Citra Pustaka, Yogyakarta

Suwartono, 2014, Dasar-Dasar Metodologi Penelitian, Andi Ofset, Yogyakarta

Zainuddin Ali, 2009, Metode Penelitian Hukum, Jakarta: Sinar Grafika

\section{Peraturan Perundang-Undangan}

Undang-Undang Dasar Negara Republik Indonesia Tahun 1945;

Undang Undang Nomor 25 Tahun 1999 tentang Perimbangan Keuangan Antara Pemerintah Pusat Dan Daerah;

Undang Undang Nomor 28 Tahun 1999 tentang Penyelenggaraan Negara Yang Bersih Dan Bebas Dari Korupsi, Kolusi, Dan Nepotisme;

Undang-Undang Nomor 17 Tahun 2003 tentang keuangan Negara;

Undang Undang Nomor 23 Tahun 2014 tentang Pemerintahan Daerah;

Peraturan Daerah Nomor 15 Tahun 2011 tentang Retribusi Izin Mendirikan Bangunan (IMB);

Menurut Keputusan MENPAN Nomor 63 tahun 2003 tentang Pedoman Umum Penyelenggaraan Pelayanan Publik;

Penjelasan umum yang dimuat di dalam Lampiran 3 Keputusan Menpan Nomor 63/Kep/M.PAN/7/2003 tentang Pedoman Umum
Penyelenggaraan Pelayanan Publik

\section{Internet}

Endang Larasati, Kontruksi Pelayanan Publik di Indonesia, Jurnal Hukum, http://www.foxitsoftware.com

https://id.wikipedia.org/wiki/Izin_Mend irikan_Bangunan 